\title{
A PROSPECTIVE STUDY TO EVALUATE THE EFFECTS OF SODIUM ALENDRONATE (AN ORAL BISPHOSPHONATE) ON BONE MINERAL DENSITY (BMD) IN PATIENTS WITH CARCINOMA PROSTATE TREATED WITH HORMONAL MANIPULATION
}

\author{
Jindal Arun ${ }^{1}$, Jindal Puja ${ }^{2}$ \\ ${ }^{1}$ Assistant Professor, Department of General Surgery, WCMSRM, Jhajjar, Haryana. \\ ${ }^{2}$ Assistant Professor, Department of Anaesthesia, WCMSRM, Jhajjar, Haryana.
}

\section{ABSTRACT}

\section{BACKGROUND}

Objective- A prospective study to evaluate the effects of Sodium Alendronate (an oral bisphosphonate) on Bone Mineral Density (BMD) in patients with carcinoma prostate treated with hormonal manipulation.

\section{MATERIALS AND METHODS}

We studied 40 patients of prostatic adenocarcinoma who underwent bilateral orchidectomy for androgen deprivation therapy. All patients underwent BMD measurement at Lumbar 1 - Lumbar 3 (L1 - L3) vertebrae using Quantitative Computerised Tomography (QCT). All patients were treated with Sodium Alendronate, (Tab. Osteophos). These were followed up at 6 months to assess the BMD.

\section{RESULTS}

The baseline average bone mineral density in the study population was $98.32+29.03 \mathrm{mg} / \mathrm{mL}$ with $\mathrm{T}$ score of $-2.56+0.963$. At 6 months, percentage fall in average BMD at six months was $1.09 \%$ and was statistically not significant. ( $\mathrm{P}$ value $=0.963$ ).

\section{CONCLUSION}

Thus, our study showed that alendronic acid is effective in the prevention of loss of BMD in patients with carcinoma prostate.

\section{KEYWORDS}

Carcinoma Prostate, Bone Mineral Density, Alendronic Acid, Androgen Deprivation Therapy.

HOW TO CITE THIS ARTICLE: Arun J, Puja J. A prospective study to evaluate the effects of sodium alendronate (an oral bisphosphonate) on Bone Mineral Density (BMD) in patients with carcinoma prostate treated with hormonal manipulation. J. Evolution Med. Dent. Sci. 2017;6(29):2387-2390, DOI: 10.14260/Jemds/2017/514

\begin{abstract}
BACKGROUND
Prostate cancer is the most common cancer. Androgen Deprivation Therapy (ADT) in the form of bilateral orchiectomy is a common form of treatment in metastatic prostate cancer. Although effective, ADT is not free from side effects. Osteoporosis is an important complication of this therapy. ${ }^{1}$ This therapy leads to accelerated loss of bone mineral density. The loss of bone mineral density has been reported to be more than $5 \%$ per year in patients with carcinoma prostate after bilateral orchidectomy. So far there are only a few studies evaluating the role of bisphosphonates in prevention of loss of bone mineral density after bilateral orchidectomy. The present study was designed to evaluate the effect of Sodium Alendronate (an oral bisphosphonate), on bone mineral density in patients with carcinoma prostate treated with hormonal manipulation.
\end{abstract}

\section{MATERIALS AND METHODS}

We prospectively studied a total of 40 patients, who underwent bilateral orchidectomy for treatment of advanced carcinoma prostate. We included only those patients who were biopsy proven, osteopenic or osteoporotic based on

Financial or Other, Competing Interest: None.

Submission 03-03-2017, Peer Review 27-03-2017,

Acceptance 03-04-2017, Published 10-04-2017.

Corresponding Author:

Dr. Jindal Arun,

H. No. 1396/17,

Ramgali, Railway Road, Rohtak.

E-mail: drarun340553@gmail.com

DOI: $10.14260 /$ jemds $/ 2017 / 514$

\section{(c) (i) $\ominus$}

BMD at primary evaluation or at followup and who gave written informed consent. Exclusion criteria included patients exhibiting metastasis at L1-L3, Chronic renal failure, Metabolic bone disease, other malignancies of prostate, Contraindications of the Alendronate i.e. hypersensitivity, Acid peptic disease etc. and patients taking steroids.

Patients underwent complete routine evaluation including history, general physical examination and routine investigations like haemogram, renal function tests, liver function tests, prostate specific antigen and any other specific investigations like bone scan if required. Relevant history, QCT was obtained before starting alendronate and at 6 months of followup during treatment.

\section{Quantitative Computed Tomography (QCT)}

Vertebral mineral content was measured by a commercial CT scanner (GE, high speed QXI or light speed plus) at $160 \mathrm{~mA}$ and $120 \mathrm{KV}$ using standard technique. T score and $\mathrm{Z}$ score were calculated. T score was calculated as Standard Deviation (SD) below the BMD of a young adult, aged 30 - 40 years and $\mathrm{Z}$ score as SD as compared to BMD of a person of same age and sex.

Patients were advised to take tablet Osteophos $70 \mathrm{mg}$ (Sodium Alendronate equivalent to Alendronic acid $70 \mathrm{mg}$, manufactured by Cipla) once a week. Patients were advised to take the tablet on a selected day of the week. Tablet was given in the morning empty stomach along with $200 \mathrm{~mL}$ of water and patients were advised to stay upright for at least 30 mins. after intake of the tablet. Patients were also advised to wait for at least 30 minutes after tablet is taken for the first food or beverage. Patients were also advised to take calcium 
$500 \mathrm{mg}$ and vitamin $\mathrm{D}_{3} 250 \mathrm{IU}$, three times a day (as tablet Shelcal, manufactured by Elders Pharmaceuticals). Patients were encouraged to maintain their physical activity and avoid smoking and alcohol.

Patients were followed up at 3 months and 6 months and were evaluated for adverse effects, particularly acid peptic disease along with its duration. A repeat QCT was obtained at 6 months.

Results of the BMD were presented as value in $\mathrm{mg} / \mathrm{mL}$ at L1, L2 and L3 levels separately as well as the average of all the three. T score and Z score were calculated. Pre- and postdrug BMD at L1-L3, average BMD, $\mathrm{T}$ and $\mathrm{Z}$ score was compared statistically. Absolute and percentage change at L1L3, and average BMD was calculated and so was the absolute change in $\mathrm{T}$ and $\mathrm{Z}$ score. Incidence of adverse effects was also recorded. Data was analysed using SPSS 10.0 computer software for windows. Power of the study was calculated using baseline mineral density of $119.2+34.9 \mathrm{mg} / \mathrm{cc}$ and expected fall of $13 \%$ over 6 months as per study of Dr. Mayank M Aggarwal using alpha power of 0.05 and beta value of $80 \%$ (study group vs. general population and continuous variable).

\section{RESULTS}

In this study, a total of 50 patients were enrolled. All patients underwent bilateral total orchidectomy for treatment of carcinoma prostate. Five patients were lost to follow up. Two patients died during followup, one because of cancer cachexia and the other due to disseminated tuberculosis. One patient was excluded from the study as he developed bilateral hydroureteronephrosis with obstructive uropathy with chronic renal failure due to the progression of the disease. One patient developed allergic rash with alendronate and so discontinued the treatment. Another patient completed 6 months of followup when he was detected to have metastasis at lumbar vertebrae, so was excluded from analysis. Data from 40 patients were analysed.

\section{Patient Profile $(n=40)$}

Age- mean age of our patients was $68.65+6.12$ years. The range was between 60 - 80 years. Age distribution of the patients is shown in Table 1 .

\begin{tabular}{|c|c|c|}
\hline $\begin{array}{c}\text { Age Group } \\
\text { (In Years) }\end{array}$ & $\begin{array}{c}\text { Number of } \\
\text { Patients }\end{array}$ & \% of Patients \\
\hline$<60$ & 4 & $10 \%$ \\
\hline $61-70$ & 20 & $50 \%$ \\
\hline $71-80$ & 16 & $40 \%$ \\
\hline \multicolumn{2}{|c|}{ Table 1. Frequency Distribution according to Age } \\
\hline
\end{tabular}

Time since castration- most of the included in the study were within 1 year of castration. Most of the patients' mean time since castration was $11.90+15.75$ months with a range of $1-60$ months. The frequency distribution of time since surgical castration is shown in Table 2 .

\begin{tabular}{|c|c|c|}
\hline $\begin{array}{c}\text { Time Since Castration } \\
\text { (In Months) }\end{array}$ & $\begin{array}{c}\text { Number of } \\
\text { Patients }\end{array}$ & $\begin{array}{c}\% \text { of } \\
\text { Patients }\end{array}$ \\
\hline $1-12$ & 26 & $65 \%$ \\
\hline $13-24$ & 8 & $20 \%$ \\
\hline $25-36$ & 2 & $5 \%$ \\
\hline $37-48$ & 2 & $5 \%$ \\
\hline $48-60$ & 2 & $5 \%$ \\
\hline \multicolumn{2}{|c|}{$\begin{array}{c}\text { Table 2. Frequency Distribution according to Time Since } \\
\text { Castration }\end{array}$} \\
\hline
\end{tabular}

Baseline bone mineral density - Baseline bone mineral density in the study population was $98.32+29.03 \mathrm{mg} / \mathrm{mL}$ with $\mathrm{T}$ score of $-2.56+0.963$

\section{Followup at 3 Months}

At 3 months of followup, none of the patients had recent onset bone pain or non-violent fracture. No significant drug related side effect was noticed except in one patient who had epigastric discomfort. This patient was found to have gall stone disease on further investigation, which was treated and symptoms subsided considerably after treatment. The change in the haematological and biochemical parameters was also recorded and none of these was found to be significant. The changes are shown in Table 3.

\begin{tabular}{|c|c|c|c|c|}
\hline Parameter & $\begin{array}{c}\text { At } \\
\text { Baseline }\end{array}$ & $\begin{array}{c}\text { At 3 } \\
\text { Months }\end{array}$ & Change & $\begin{array}{c}\text { P } \\
\text { value }\end{array}$ \\
\hline $\begin{array}{c}\text { Haemoglobin } \\
\text { (gm\%) }\end{array}$ & 11.74 & 11.77 & +0.03 & 0.946 \\
\hline TLC (per mL) & 6975.00 & 7833.50 & +858.50 & 0.212 \\
\hline Calcium (mg\%) & 9.30 & 9.16 & -0.14 & 0.427 \\
\hline $\begin{array}{c}\text { Inorg. Phosphate } \\
\text { (mg\%) }\end{array}$ & 4.07 & 4.07 & -0.005 & 0.974 \\
\hline $\begin{array}{c}\text { Alk. Phosphatase } \\
\text { (K.A.U) }\end{array}$ & 7.15 & 8.10 & +0.95 & 0.075 \\
\hline SGOT (IU) & 12.40 & 16.10 & +3.70 & 0.259 \\
\hline SGPT (IU) & 11.75 & 16.95 & +5.20 & 0.165 \\
\hline
\end{tabular}

Table 3. Change in the Laboratory Parameters at 3 Months

\section{Followup at 6 Months}

At 6 months of followup, none of the patients had new onset bone pain or nonviolent fracture. No significant drug related side effect was noticed.

\section{BMD Changes at 6 Months}

Following changes in BMD were noticed at 6 months of followup.

\section{Changes in Average BMD}

The mean average BMD at baseline was $98.32+29.03$ $\mathrm{mg} / \mathrm{mL}$. It showed a fall of $0.14 \mathrm{mg} / \mathrm{mL}(1.09 \%)$ at 6 months. The fall in BMD at 6 months was statistically not significant ( $p$ value $=0.963$ ). Overall, average BMD showed a rise in 13 and fall in 7 patients. Table 4 summarises the changes in the BMD at 6 months.

\begin{tabular}{|c|c|c|c|c|c|}
\hline Parameter & $\begin{array}{c}\text { At } \\
\text { Baseline }\end{array}$ & $\begin{array}{c}\text { At 6 } \\
\text { Months }\end{array}$ & Change & $\begin{array}{c}\text { \% } \\
\text { Change }\end{array}$ & $\begin{array}{c}\text { P } \\
\text { value }\end{array}$ \\
\hline $\begin{array}{c}\text { BMD at L1 } \\
(\mathrm{mg} / \mathrm{mL})\end{array}$ & 101.38 & 100.46 & -0.92 & -1.66 & 0.747 \\
\hline $\begin{array}{c}\mathrm{BMD} \text { at L2 } \\
(\mathrm{mg} / \mathrm{mL})\end{array}$ & 96.74 & 96.68 & -0.06 & -0.09 & 0.986 \\
\hline $\begin{array}{c}\mathrm{BMD} \text { at L3 } \\
(\mathrm{mg} / \mathrm{mL})\end{array}$ & 97.13 & 98.37 & +1.23 & +1.34 & 0.774 \\
\hline $\begin{array}{c}\text { Average } \\
\text { BMD } \\
(\mathrm{mg} / \mathrm{mL})\end{array}$ & 98.32 & 98.18 & -0.14 & -1.09 & 0.963 \\
\hline T Score & -2.56 & -2.49 & +0.07 & - & 0.516 \\
\hline Z Score & -0.20 & -0.28 & -0.08 & - & 0.694 \\
\hline Table 4. Changes in BMD at 6 Months of Alendronate \\
\multicolumn{7}{|c|}{ Treatment } \\
\hline
\end{tabular}




\section{Baseline Factors affecting \% Change in Average BMD Table V:}

The \% change in average BMD was calculated separately for men $>70$ years and $<$ than 70 years of age, for osteopenic and osteoporotic patients and for patients with castration duration less than and more than one year. The difference of changes in percentage average BMD with use of alendronate was probably significant in relation to time since castration and those who are one year post castration or more showed significant improvement as compared to men who are less than one year post castration who showed a fall even with use of alendronate. The change in \% average BMD was not significantly different in relation to age and baseline BMD status. The results are shown in Table 5.

\begin{tabular}{|c|c|c|c|}
\hline Parameter & Group & Mean & P value \\
\hline \multirow[t]{2}{*}{ Age (In Years) } & $>70$ & $-7.08+21.54$ & 0.189 \\
\hline & $<70$ & $+2.89+11.10$ & \\
\hline \multirow[t]{2}{*}{$\begin{array}{l}\text { Time Since } \\
\text { Castration }\end{array}$} & $<1$ year & $-6.84+16.75$ & 0.028 \\
\hline & $>1$ year & $+9.58+9.00$ & \\
\hline \multirow[t]{2}{*}{ BMD } & Osteopenic & $-0.45+13.24$ & 0.867 \\
\hline & Osteoporotic & $-1.72+19.71$ & \\
\hline $\begin{array}{r}\text { Table 5. \% C } \\
\text { Treatme }\end{array}$ & ges in Averag & $\begin{array}{l}\text { BMD with Ale } \\
\text { aseline Paran }\end{array}$ & $\begin{array}{l}\text { dronate } \\
\text { ters }\end{array}$ \\
\hline
\end{tabular}

So, the difference of changes in percentage average BMD with use of alendronate was probably significant in relation to time since castration and those who are one year post castration or more showed significant improvement as compared to men who are less than one year post castration who showed a fall even with use of alendronate. The change in \% average BMD was not significantly different in relation to age and baseline BMD status. The change in the haematological and biochemical parameters was also recorded at 6 months and none of these was found to be significant. The changes are shown in the Table 6.

\begin{tabular}{|c|c|c|c|c|}
\hline Parameter & $\begin{array}{c}\text { At } \\
\text { Baseline }\end{array}$ & $\begin{array}{c}\text { At 6 } \\
\text { Months }\end{array}$ & Change & $\begin{array}{c}\text { P } \\
\text { value }\end{array}$ \\
\hline $\begin{array}{c}\text { Haemoglobin } \\
\text { (gm\%) }\end{array}$ & 11.74 & 11.69 & -0.05 & 0.923 \\
\hline TLC (per mL) & 6975.00 & 7810 & +835 & 0.167 \\
\hline Calcium (mg \%) & 9.30 & 9.18 & -0.12 & 0.541 \\
\hline $\begin{array}{c}\text { Inorg. } \\
\text { Phosphate } \\
\text { (mg\%) }\end{array}$ & 4.07 & 4.04 & -0.03 & 0.837 \\
\hline $\begin{array}{c}\text { Al. phosphatase } \\
\text { (K.A.U) }\end{array}$ & 7.15 & 7.75 & +0.6 & 0.374 \\
\hline SGOT (IU) & 12.40 & 15.40 & +3.00 & 0.481 \\
\hline SGPT (IU) & 11.75 & 13.90 & +2.15 & 0.581 \\
\hline Table 6. Laboratory Parameters at Baseline and at 6 \\
Months of Treatment
\end{tabular}

\section{DISCUSSION}

Androgen deprivation therapy has an important role in the treatment of carcinoma prostate. Surgical or medical castration is the gold standard of therapy in patients with metastatic carcinoma 2,3 and may be required in a number of patients who are initially treated with radical surgery or radiotherapy.4,5,6 Most patients in our study underwent bilateral orchidectomy for either metastatic or locally advanced prostate cancer.
ADT can have significant side effects in the form of impotence, $, 7,8,9$ hot flashes, ${ }^{10}$ anaemia, ${ }^{11,12}$ loss of muscle mass, loss of libido and loss of bone mass. ${ }^{13-16}$ These are primarily because of lowering in the levels of serum testosterone. Osteopenia or osteoporosis develops progressively 13 in a number of patients and can be a cause of significant mortality, ${ }^{17}$ primarily because of incidence of hip fractures. In an Indian study, Mayank et al ${ }^{18}$ reported $12 \%$ and $18 \%$ bone loss at 6 and 12 months respectively after orchidectomy.

In our study, patients with normal bone mineral density were excluded. The incidence of osteopenic and osteoporotic patients was equal in our study, $50 \%$ each. Baseline bone mineral density in our study population as measured by QCT was $98.32+29.03 \mathrm{mg} / \mathrm{mL}$, which is only slightly more than that reported by Smith et al ${ }^{19}(97.60 \mathrm{mg} / \mathrm{mL})$.

BMD is the gold standard of evaluation for these patients and can be measured with either QCT or DEXA. QCT is more sensitive than DEXA to detect changes in bone mineral density, particularly in old age because of effects of spinal osteoarthritis. It can measure the changes in BMD at trabecular bone separately, which has a higher turnover rate $^{20,21,22}$ and so is affected earlier. In our study, we measured BMD using QCT at L1-L3 vertebrae.

Various bisphosphonates have been used to manage osteoporosis in patients of carcinoma prostate. Pamidronate along with calcium and vitamin $\mathrm{D}$ has been used by Smith et $\mathrm{al}^{19}$ in patients who were treated with LHRH agonists. The authors reported a $2 \%$ fall in average lumbar spine BMD at 1 year as compared to the control group, which showed an $8.5 \%$ fall at one year.

Zoledronic acid ${ }^{23}$ has been used in patients with nonmetastatic carcinoma prostate treated with maximal androgen blockage or LHRH agonists. The authors reported increase of average spinal BMD by $5.60 \%$ at one year as measured by DEXA in contrast to the control group, which showed a fall of $2.2 \%$.

Alendronate has not been studied in carcinoma prostate patients treated with androgen deprivation therapy. It has largely been studied in postmenopausal women and found to be effective in this population. Orwoll et $\mathrm{al}^{24}$ studied the role of alendronate in the treatment of primary osteoporosis in men. The authors reported $4 \%$ increase in average lumbar spine BMD using QCT at 6 months and $8 \%$ increase at 2 years. The lower response observed in our study may be attributed to the high rate of bone loss (about 5\% - 10\% per year) in post castration patients as compared to the age related bone loss, which is about $5 \%-10 \%$ per decade. This is further supported by the fact that in more than one year post castration group there was a rise of $9.58 \%$ in average lumbar spine BMD as compared to a fall of $6.84 \%$ in patients who were less than one year post castration. This is because of higher rate of bone loss in immediate post castration period.

We found that alendronate is effective in the prevention of loss of bone mass in patients with carcinoma prostate treated with androgen deprivation therapy. At 6 months, the average BMD at lumbar spine decreased by $1.09 \%$ in treated population, which is not statistically significant. This fall of average BMD at lumbar vertebra by $1.09 \%$ at 6 months is much lower as compared to $12 \%$ fall in a similar population of untreated patients at the same site at 6 months as reported by Mayank et al.18 
The incidence of side effects with once weekly alendronate is low and gastrointestinal side effects are comparable with that of placebo. ${ }^{25}$ In our study one patient complained of upper gastrointestinal discomfort, which on subsequent evaluation was found to be due to gall stone disease. It improved significantly following cholecystectomy. We did not find any significant change in haemoglobin, total leucocyte counts, liver enzymes, calcium and inorganic phosphate.

\section{CONCLUSION}

Thus, our study showed that alendronic acid, used as sodium alendronate $70 \mathrm{mg}$, once a week is effective in the prevention of loss of bone mineral density in patients with carcinoma prostate. Alendronate is safe and is well tolerated in our study population. Long term followup studies with a larger group of patients are required to further document its role in the management of osteoporosis in patients undergoing hormone deprivation therapy for carcinoma prostate as well as to establish their role in reduction of fracture risk at spinal and non-spinal sites.

\section{REFERENCES}

[1] Epstein JI, Partin AW, Potter SR, et al. Adenocarcinoma of the prostate invading the seminal vesicle: prognostic stratification based on pathological parameters. Urology 2000;56(2):283-8.

[2] Huggins C, Hodges CV. The effect of castration of estrogen and of androgen injection on serum phosphatases in metastatic carcinoma of the prostate. Cancer Res 1941;1:293-7.

[3] Huggins C, Stevens RE, Hodges CV. Studies on prostate cancer II. The effects of castration on advanced carcinoma of prostate gland. Arch Surgery 1941;43(2):209-23.

[4] Ferguson JK, Oesterling JE. Patient evaluation if prostate-specific antigen becomes elevated following radical prostatectomy or radiation therapy. Urol Clin North Am 1994;21(4):677-85.

[5] Bolla M, Collette L, Warde P. Long term results of immediate adjuvant hormonal therapy with goserelin in patients with locally advanced prostate cancer treated with radiotherapy. A phase 3 EORTC study. Int J Radiat Onco Biol Phys 1999;45(Supple 3):147.

[6] Bolla M, Gonzalez D, Warde P, et al. Improved survival in patients with locally advanced prostatic cancer treated with radiotherapy and goserelin. $\mathrm{N}$ Engl J Med 1997;337(5):295-300.

[7] Lamberts SW, Beld VDAW, Lely VDAJ. The endocrinology of aging. Science 1997;278(5337):41924.

[8] Clarke NW, McClure J, George NJ. The effects of orchidectomy on skeletal metabolism in metastatic prostate cancer. Scand J Urol Nephrol 1993;27(4):475-83.

[9] Thompson CA, Shanafelt TD, Loprinzi CL. Andropause: symptom management for prostate cancer patients treated with hormonal ablation. The Oncologist 2003;8(5):474-87.
[10] Charig CR, Rundle JS. Flushing. Long-term side effect of orchiectomy in treatment of prostatic carcinoma. Urology 1989;33(3):175-8.

[11] Evens RP, Amerson AB. Androgens and erythropoiesis. J Clin Pharmacol 1974;14(2):94-101.

[12] Strum SB, McDermed JE, Scholz MC, et al. Anaemia associated with androgen deprivation in patients with prostate cancer receiving combined hormone blockade. Br J Urol 1997;79(6):933-41.

[13] Daniell HW. Osteoporosis after orchiectomy for prostatic cancer. J Urol 1997;157(2):439-44.

[14] Townsend MF, Sanders WH, Northway RO, et al. Bone fractures associated with luteinising hormone releasing hormone agonists used in the treatment of prostate carcinoma. Cancer 1997;79(3):545-50.

[15] Hatano T, Oishi Y, Furuta A, et al. Incidence of bone fractures in patients receiving luteinizing hormone releasing hormone for prostate cancer. BJU int 2000;86(4):449-52.

[16] Oefelein MG, Ricchuiti V, Conrad W, et al. Skeletal fractures associated with androgen suppression induced osteoporosis: the clinical incidence and risk factors for patients with prostate cancer. J Urol 2001;166(5):1724-8.

[17] Smith MR. Osteoporosis during androgen deprivation therapy for prostate cancer. Urology 2002;60(3 Suppl 1):79-86.

[18] Agarwal MM, Khandelwal N, Mandal AK, et al. Factors affecting bone mineral density in patients with prostate carcinoma before and after orchidectomy. Cancer 2005;103(10):2042-52.

[19] Smith MR, McGovern FJ, Zietmen AL, et al. Pamidronate to prevent bone loss during androgen deprivation therapy for prostate cancer. N Engl J Med 2001;345:948-55.

[20] Pacifici R, Rupich R, Griffin M, et al. Dual energy radiography versus quantitative computer tomography for the diagnosis of osteoporosis. J Clin Endo Metab 1990;70(3):705-10.

[21] Yu W, Gluer GC, Grampp S, et al. Spinal bone mineral assessment in postmenopausal women: a comparison between dual X-ray absorptiometry and quantitative computed tomography. Osteoporos int 1996;5(6):433-9.

[22] Smith MR, McGovern FJ, Fallon MA, et al. Low bone mineral density in hormone-naïve men with prostate carcinoma. Cancer 2001;91(12):2238-45.

[23] Smith MR, Eastham J, Gleason DM, et al. Randomized controlled trial of zoledronic acid to prevent bone loss in men receiving androgen deprivation therapy for nonmetastatic prostate cancer. J Urol 2003;169(6):2008-12.

[24] Orwoll E, Ettinges M, Weiss S, et al. Alendronate for treatment of osteoporosis in men. $\mathrm{N}$ Engl J Med 2000;343:604-10.

[25] Greenspan S, Munves EF, Tonino R, et al. Tolerability of once weekly alendronate in patients with osteoporosis: a randomized, double blind, placebo controlled study. Mayo Clin Proc 2002;77(10):104452. 